\title{
Oxalate-rich foods
}

\author{
Roswitha SIENER ${ }^{1 *}$ (D), Ana SEIDLER ${ }^{1}$, Ruth HÖNOW ${ }^{2}$
}

\begin{abstract}
The intake of large amounts of the antinutrient oxalate can induce hyperoxaluria, an important risk factor for the development of calcium oxalate stones. The soluble and total oxalate concentrations of plants of the Fabaceae, Convolvulaceae, and Malvaceae families were determined using an HPLC-enzyme-reactor method. Sweet potato is a species of the Convolvulaceae, Fabaceae includes beans, lentils, peas, licorice and blue fenugreek, whereas okra and cocoa are species of the Malvaceae family. Total oxalate content was highest in licorice root (Glycyrrhiza glabra; $3569 \mathrm{mg} / 100 \mathrm{~g}$ ), an important medicinal herb and sweetener in candies, blue fenugreek (Trigonella coerulea; $1246 \mathrm{mg} / 100 \mathrm{~g}$ ) and white beans (Phaseolus vulgaris L.; $548 \mathrm{mg} / 100 \mathrm{~g}$ ), plants of the Fabaceae family. Total oxalate content amounted to $496 \mathrm{mg} / 100 \mathrm{~g}$ in sweet potato (Ipomoea batatas), $619 \mathrm{mg} / 100 \mathrm{~g}$ in cocoa powder (Theobroma cacao) and $317 \mathrm{mg} / 100 \mathrm{~g}$ in okra (Abdelmoschus esculentus), the most important agricultural crops of the Convolvulaceae and Malvaceae, respectively. The findings suggested that most foods of these plant families contain high to excessively high oxalate concentrations. The consumption of these oxalate-rich plants can negatively impact calcium oxalate stone formation.
\end{abstract}

Keywords: oxalic acid; calcium oxalate stone formation; licorice root; fenugreek; pulses; legume seeds.

Practical Application: Procedures to reduce the oxalic acid content of oxalate-rich foods are required.

\section{Introduction}

High consumption of dietary oxalate constitutes a considerable health concern mainly due to the property of oxalic acid to form insoluble salts with divalent cations such as calcium or magnesium. About $70 \%$ of all urinary calculi mainly consist of calcium oxalate (Lieske et al., 2014). Secondary hyperoxaluria, either based on increased intestinal absorption or high dietary intake of oxalate, is regarded as a major risk factor for calcium oxalate stone formation (Siener et al., 2003). Furthermore, the antinutrient oxalic acid has been shown to impair the absorption of magnesium, zinc, iron and calcium in the intestine by complexation (Kelsay \& Prather, 1983; Heaney et al., 1988; Noonan \& Savage, 1999; Bohn et al., 2004).

Oxalate is a ubiquitious metabolic end product in plants. The oxalate content of most foods in a typical Western diet has been reported to be low to moderate (Hönow \& Hesse, 2002). However, some plants are known to accumulate large amounts of oxalate. The families Amaranthaceae, Chenopodiaceae and Polygonaceae comprise most of the plants with exceptionally high oxalate concentrations, e.g. spinach, sorrel, rhubarb, mangold and amaranth (Siener et al., 2006).

In contrast to spinach and rhubarb, reliable data on the oxalate concentration of species of further plant families are incomplete or lacking. Legumes, i.e. beans, lentils and peas, species of the Fabaceae family, play a significant role in the traditional diets of many countries throughout the world (Messina, 1999). Licorice root, an important medicinal herb and sweetener in candies, and blue fenugreek are also assigned to the Fabaceae. Demand for okra, a species of the Malvaceae family cultured in tropical and subtropical regions, is growing worldwide owing to its palatability and nutritional value. Cocoa is another important agricultural crop in the Malvaceae family. Moreover, sweet potato, the only species of major importance as foodstuff of Convolvulaceae, is becoming increasingly popular and is recommended even for young children due to its high beta-carotene content, a provitamin A carotenoid (Hotz et al., 2012).

The contribution of dietary oxalate to the amount of oxalate excreted in urine is estimated to be up to $50 \%$ on average (Holmes et al., 2001). A reasonable goal for patients with idiopathic or enteric hyperoxaluria is to limit dietary oxalate intake to less than $100 \mathrm{mg}$ daily. Knowledge of the amount of oxalate in foods is therefore highly relevant for the recurrence prevention of calcium oxalate urolithiasis (Hesse et al., 2009). The aim of this study was to determine the total and soluble oxalate concentrations of plants of the Fabaceae, Convolvulaceae and Malvaceae families for the development of dietary recommendations for calcium oxalate stone patients.

\section{Materials and methods}

The oxalate content of eight species from the family Fabaceae, and cocoa, okra and sweet potato, the only species of major importance as foodstuffs of Malvaceae and Convolvulaceae families, respectively, was examined. All food samples were purchased at local establishments in the area of Bonn, Germany. The species are presented in Tables 1 and 2. 
Table 1. Oxalate content of species of the Fabaceae family.

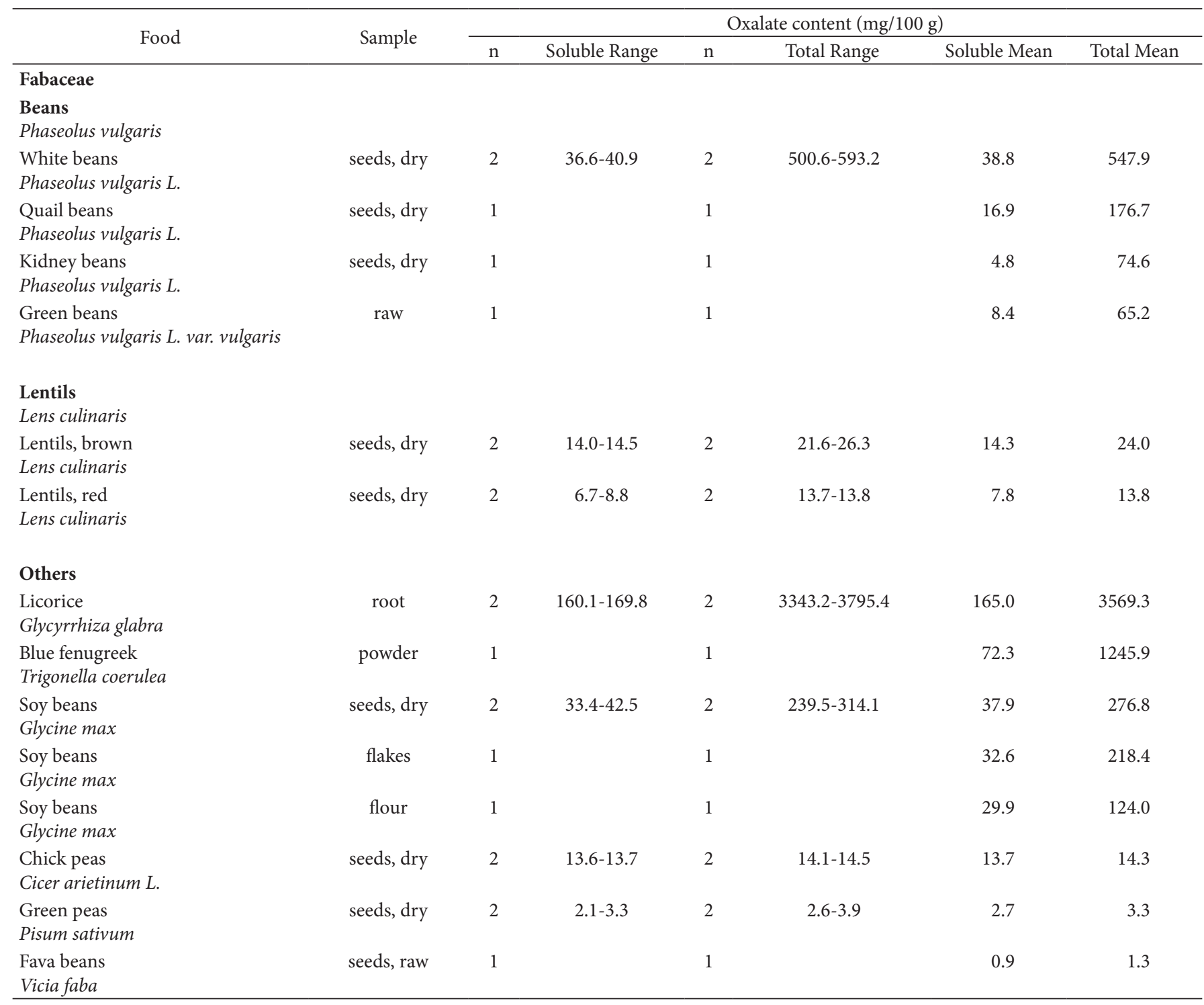

\subsection{Sample preparation}

Total oxalate was extracted by suspending $2.0 \mathrm{~g}$ of the homogenized samples with $4.0 \mathrm{~mL} 2 \mathrm{~N} \mathrm{HCl}$ (Merck, Germany) at $21^{\circ} \mathrm{C}$ for $15 \mathrm{~min}$ (Hönow \& Hesse, 2002; Siener et al., 2006). Soluble oxalate was extracted from another $2.0 \mathrm{~g}$ samples with $4.0 \mathrm{~mL}$ distilled water (J.T. Baker Water; HPLC reagent, The Netherlands) at $21^{\circ} \mathrm{C}$ for $15 \mathrm{~min}$. To inhibit neogenesis of oxalate from ascorbic acid which may have been present, the filtrates were acidified with $50 \mu \mathrm{l} 2 \mathrm{~N} \mathrm{HCl} / \mathrm{mL}$ (Hönow \& Hesse, 2002; Siener et al., 2006). Duplicate oxalate analyses were carried out for each sample, including both oxalate extraction methodologies. The number of different food samples (n) is shown in the tables.

\subsection{Determination of total and soluble oxalate}

Total and soluble oxalate contents of the extracted samples were immediately determined using a high-performance liquid chromatography (HPLC)-enzyme-reactor method as outlined by Siener et al. (2017) and Hönow \& Hesse (2002). The HPLC-enzyme-reactor method combines the selectivity of a chromatographic separation of oxalate with the enzymatic conversion and amperometric detection (Hönow et al., 1997). The chromatographic separation was performed using an anion exchange column (AS4A-DIONEX, ThermoFisher Scientific, USA) and a mobile phase of an aqueous EDTA solution $(2.0 \mathrm{~g} / \mathrm{L}$, adjusted to pH 5.0 with $0.3 \mathrm{~mol} / \mathrm{L} \mathrm{NaOH}$ ) (Merck, Germany). The enzyme reactor consisted of 5 units of immobilized oxalate oxidase (oxalate oxidase: E.C. 1.2.3.4.; Sigma Diagnostics, USA), which converted oxalate to hydrogen peroxide and carbon dioxide. The determination of hydrogen peroxide based on amperometric detection (Hönow et al., 1997).

\section{Results}

The most important agricultural crops in the Convolvulaceae, Fabaceae and Malvaceae families are presented in Tables 1 and 2 .

Sweet potato is the only species of major importance as foodstuff of the Convolvulaceae, Fabaceae includes beans, lentils, 
Table 2. Oxalate content of species of the Convolvulaceae and Malvaceae families.

\begin{tabular}{|c|c|c|c|c|c|c|c|}
\hline \multirow{2}{*}{ Food } & \multirow{2}{*}{ Sample } & \multicolumn{6}{|c|}{ Oxalate content $(\mathrm{mg} / 100 \mathrm{~g})$} \\
\hline & & $\mathrm{n}$ & Soluble Range & $\mathrm{n}$ & Total Range & Soluble Mean & Total Mean \\
\hline \multicolumn{8}{|l|}{ Convolvulaceae } \\
\hline $\begin{array}{l}\text { Sweet potato } \\
\text { Ipomoea batatas }\end{array}$ & raw & 2 & $68.0-85.4$ & 2 & $467.3-523.9$ & 76.7 & 495.6 \\
\hline \multicolumn{8}{|l|}{ Malvaceae } \\
\hline $\begin{array}{l}\text { Cocoa } \\
\text { Theobroma cacao L. }\end{array}$ & powder & 1 & & 1 & & 571.3 & 619.3 \\
\hline
\end{tabular}

peas, licorice root and blue fenugreek, whereas okra and cocoa are species of the Malvaceae family. Except for peas, lentils and fava bean, foods of these plant families contained high to excessively high oxalate concentrations.

Total oxalate content was highest in licorice root (Glycyrrhiza glabra; $3569.3 \mathrm{mg} / 100 \mathrm{~g}$ ), blue fenugreek (Trigonella coerulea; $1245.9 \mathrm{mg} / 100 \mathrm{~g}$ ) and white beans (Phaseolus vulgaris L.; $547.9 \mathrm{mg} / 100 \mathrm{~g}$ ), species of the Fabaceae family. Total oxalate concentration was $495.6 \mathrm{mg} / 100 \mathrm{~g}$ in sweet potatoes (Ipomoea batatas), $619.3 \mathrm{mg} / 100 \mathrm{~g}$ in cocoa powder (Theobroma cacao) and $317.2 \mathrm{mg} / 100 \mathrm{~g}$ in okra (Abdelmoschus esculentus), species of the Convolvulaceae and Malvaceae families, respectively. In contrast, total oxalate content was low in fava beans (Vicia faba), green peas (Pisum sativum), chick peas (Cicer arietinum L.) and lentils (Lens culinaris), ranging from 1.3 to $24.0 \mathrm{mg} / 100 \mathrm{~g}$. Overall, soluble oxalate ranged from 0.9 to $571.3 \mathrm{mg} / 100 \mathrm{~g}$. Soluble oxalate was highest in cocoa powder (Theobroma cacao; $571.3 \mathrm{mg} / 100 \mathrm{~g}$ ) and licorice root (Glycyrrhiza glabra; $165.0 \mathrm{mg} / 100 \mathrm{~g}$ ).

\section{Discussion}

Hyperoxaluria is a major risk factor for calcium oxalate stone formation (Siener et al., 2003). Dietary hyperoxaluria can even be induced in healthy individuals without disorders of oxalate metabolism simply by ingestion of oxalate-rich foods (Siener et al., 2013). In calcium oxalate stone formers, intestinal hyperabsorption of oxalate may additionally increase urinary oxalate excretion (Voss et al., 2006). The administration of probiotics containing oxalate-degrading bacterial species could be a potential strategy to reduce the risk of calcium oxalate stone formation (Sönmez et al., 2018). However, the results from human interventional studies on the effects of probiotic treatment on urinary oxalate excretion and lithogenic risk were conflicting (Siener et al., 2013; Ticinesi et al., 2020). For the treatment of diet-dependent hyperoxaluria, calcium oxalate stone patients are therefore recommended to restrict daily oxalate ingestion to no more than $100 \mathrm{mg}$.

Findings from a previous study suggested that the oxalate content of foods is mainly determined by the plant family (Siener et al., 2006). The Polygonaceae, Amaranthaceae and Chenopodiaceae families were found to include foods with exceptionally high oxalate contents, ranging from 143 to $1959 \mathrm{mg} / 100 \mathrm{~g}$. In contrast, total oxalate concentration was below $10 \mathrm{mg} / 100 \mathrm{~g}$ in plants of the Brassicaceae family, such as broccoli, cauliflower, kohlrabi, brussels sprouts and savoy cabbage, and between approximately 10 and $20 \mathrm{mg} / 100 \mathrm{~g}$ in species of the Solanaceae family, such as tomatoes, potatoes and aubergines (Hönow \& Hesse, 2002; Siener et al., 2006). In the current study, Fabaceae included most of the foods with high oxalate contents. Total oxalate content was highest in licorice root (Glycyrrhiza glabra) and blue fenugreek (Trigonella coerulea), species of the Fabaceae family (Table 1). In fact, licorice root had a total oxalate concentration of $3569 \mathrm{mg} / 100 \mathrm{~g}$ and total oxalate of blue fenugreek powder amounted to $1246 \mathrm{mg} / 100 \mathrm{~g}$. As these plants had not previously been analyzed, data on the oxalate contents were not available. Blue fenugreek (Trigonella coerulea) is known as spice, predominantly in Alpine countries, Southern and Eastern Europe. Licorice, mainly obtained from the root of Glycyrrhiza glabra, is an important medicinal herb since ancient time with nutritional and therapeutic values (Nazari et al., 2017). Licorice extract is frequently used in traditional medicine for the treatment of several diseases, including inflammation, gastric ulcer and respiratory diseases (Yang et al., 2015), and is found in a variety of herbal teas, candies or sweets and beverages like root beer. The average daily dose for oral administration of Glycyrrhiza glabra for traditional uses as recommended in herbal literature is 5-15 $\mathrm{g}$ of powdered or comminuted root as an infusion or a decoction (European Medicines Agency, 2013). The oxalate content reported by Salawu et al. (2019) for the Glycyrrhiza glabra tea infusion ( $15 \mathrm{~g}$ licorice root infused in $1.2 \mathrm{~L}$ of hot water) was $270.1 \mathrm{mg} / \mathrm{L}$. The oxalate concentration of the hot water infusion of licorice root may vary with the brewing process of the tea, i.e. the water temperature and duration of infusion. However, the consumption of the recommended daily dose of this herbal tea can significantly increase the risk of calcium oxalate stone formation. Data on the oxalate content of licorice candies and sweets are still lacking.

The analyses of various other types of legumes of the Fabaceae family revealed a wide oxalate range of 1.3 to $547.9 \mathrm{mg} / 100 \mathrm{~g}$. The total oxalate concentration was high in white, quail, kidney and green beans (Phaseolus vulgaris) as well as soybean seeds and products (Glycine max), ranging from 65 to $548 \mathrm{mg} / 100 \mathrm{~g}$, but comparatively low in fava beans (Vicia faba), green peas (Pisum sativum), chick peas (Cicer arietinum L.) and lentils (Lens culinaris). The presently reported values for soybean were close to some of those reported for soybean seeds from 116 cultivars (Horner et al., 2005). While Shi et al. (2018) and Akhtar et al. (2011) reported higher total oxalate concentrations in 
Canadian (370.5 mg/100 g) and Pakistan soybean (497 mg/100 g), respectively, Judprasong et al. (2006) found lower levels in Thailand soybean seeds $(204 \mathrm{mg} / 100 \mathrm{~g})$ as compared to the present findings. In contrast, the total oxalate contents of whole soybeans were about 4 to 5 times higher than the values reported by Ruan et al. (2013) and Al-Wahsh et al. (2005). However, the oxalate concentration of soybean flour was between the two values reported previously (Al-Wahsh et al., 2005). Data in the literature on the oxalate content of raw lentils, peas, and fava beans are scarce. The oxalate concentrations reported by Shi et al. (2018) for Canadian pulses were considerably higher than the values presently reported. The total oxalate content found in kidney beans $(74.6 \mathrm{mg} / 100 \mathrm{~g})$, however, was close to the $107.8 \mathrm{mg} / 100 \mathrm{~g}$ dry matter in the Canadian kidney beans obtained by Shi et al. (2018) and in accordance with the $91 \mathrm{mg} / 100 \mathrm{~g}$ reported by Judprasong et al. (2006) using an HPLC method. The discrepancy in the oxalate concentrations of plant foods can be ascribed to growing conditions (e.g. light exposure, soil quality, level of maturity), harvest time, variety and different analytical methods used for oxalate extraction and determination (Shi et al., 2018).

Okra and sweet potatoes are widely accepted vegetables and are becoming increasingly popular in Europe. However, reliable data on the oxalate concentration of okra, a species of the Malvaceae, and sweet potato, the only species of major importance of Convolvulaceae, have been lacking. In the present study, the total oxalate content of okra amounted to $317.2 \mathrm{mg} / 100 \mathrm{~g}$ (Table 2). The total oxalate content of sweet potato roots was $495.6 \mathrm{mg} / 100 \mathrm{~g}$ and therefore significantly higher than that in sweet potato leaves $(58.3 \pm 2.7 \mathrm{mg} / 100 \mathrm{~g})$, petioles $(35.9 \pm 0.6 \mathrm{mg} / 100 \mathrm{~g})$ and roots $(27.6 \pm 1.3 \mathrm{mg} / 100 \mathrm{~g})$ as reported by Ruan et al. (2013) using a modified enzymatic method. Cocoa (Theobroma cacao) products are in great demand world-wide due to their unique aroma and flavour as well as potential health benefits (Nguyen et al., 2018). Total oxalate concentration of cocoa powder observed in this experiment was $619.3 \mathrm{mg} / 100 \mathrm{~g}$ which is close to the values presented by Schroder et al. (2011) and Nguyen et al. (2018).

Because the soluble form of oxalate in foods may play a crucial role in the determination of oxalate absorption in the gut, plants were further analysed for soluble oxalate concentration. Except for fava beans, green peas, chick peas and lentils, the soluble oxalate concentration of species of the Fabaceae was between 4.8 and $165.0 \mathrm{mg} / 100 \mathrm{~g}$, which is about $5-24 \%$ of the total oxalate. In contrast, the soluble oxalate content of cocoa powder was $571.3 \mathrm{mg} / 100 \mathrm{~g}$, corresponding to $92 \%$ of the total oxalate, which falls within the range values reported by Nguyen et al. (2018) and Schroder et al. (2011). So far it is unknown to what extent insoluble calcium oxalate requires dissociation prior to absorption and whether absorption of intact calcium oxalate may occur in the human intestine (Hanes et al., 1999).

\section{Conclusions}

Most of the species in the Fabaceae, Convolvulaceae and Malvaceae families contained high to excessively high oxalate concentrations. The total oxalate content was found to be highest in licorice root and blue fenugreek, species of the Fabaceae family, followed by sweet potato, cocoa powder and okra, species of the Convolvulaceae and Malvaceae families, respectively. Calcium oxalate stone patients should be encouraged to avoid these oxalate-rich foods and herbs, because the consumption of even small amounts may exceed the recommended daily oxalate ingestion of no more than $100 \mathrm{mg}$. It is suggested that the membership of species in a plant family is an important determinant of the oxalate content of foods. However, further research is needed on genetic variation in the oxalate concentration of different cultivars of fava beans, peas and lentils. Furthermore, future studies should examine the oxalate bioavailability particularly of oxalate-rich legume seeds and products. Procedures to reduce the oxalic acid content of oxalate-rich foods are required.

\section{References}

Akhtar, M. S., Israr, B., Bhatty, N., \& Ali, A. (2011). Effect of cooking on soluble and insoluble oxalate contents in selected Pakistani vegetables and beans. International Journal of Food Properties, 14(1), 241-249. http://dx.doi.org/10.1080/10942910903326056.

Al-Wahsh, I. A., Horner, H. T., Palmer, R. G., Reddy, M. B., \& Massey, L. K. (2005). Oxalate and phytate of soy foods. Journal of Agricultural and Food Chemistry, 53(14), 5670-5674. http://dx.doi.org/10.1021/ jf0506378. PMid:15998131.

Bohn, T., Davidsson, L., Walczyk, T., \& Hurrell, R. F. (2004). Fractional magnesium absorption is significantly lower in human subjects from a meal served with an oxalate-rich vegetable, spinach, as compared with a meal served with kale, a vegetable with a low oxalate content. British Journal of Nutrition, 91(4), 601-606. http://dx.doi.org/10.1079/ BJN20031081. PMid:15035687.

European Medicines Agency - EMA, Committee on Herbal Medicinal Products. (2013). Assessment report on Glycyrrhiza glabra L. and/or Glycyrrhiza inflata Bat. and/or Glycyrrhiza uralensis Fisch., radix. London: EMA.

Hanes, D. A., Weaver, C. M., Heaney, R. P., \& Wastney, M. (1999). Absorption of calcium oxalate does not require dissociation in rats. The Journal of Nutrition, 129(1), 170-173. http://dx.doi.org/10.1093/ jn/129.1.170. PMid:9915895.

Heaney, R. P., Weaver, C. M., \& Recker, R. R. (1988). Calcium absorbability from spinach. The American Journal of Clinical Nutrition, 47(4), 707-709. http://dx.doi.org/10.1093/ajcn/47.4.707. PMid:3354496.

Hesse, A., Tiselius, H. G., Siener, R., \& Hoppe, B. (2009). Urinary stones: diagnosis, treatment, and prevention of recurrence (3rd ed.) Basel: Karger. http://dx.doi.org/10.1159/isbn.978-3-8055-9150-8.

Holmes, R. P., Goodman, H. O., \& Assimos, D. G. (2001). Contribution of dietary oxalate to urinary oxalate excretion. Kidney International, 59(1), 270-276. http://dx.doi.org/10.1046/j.1523-1755.2001.00488.x. PMid:11135080.

Hönow, R., \& Hesse, A. (2002). Comparison of extraction methods for the determination of soluble and total oxalate in foods by HPLCenzyme-reactor. Food Chemistry, 78(4), 511-521. http://dx.doi. org/10.1016/S0308-8146(02)00212-1.

Hönow, R., Bongartz, D., \& Hesse, A. (1997). An improved HPLCenzyme-reactor method for the determination of oxalic acid in complex matrices. Clinica Chimica Acta, 261(2), 131-139. http:// dx.doi.org/10.1016/S0009-8981(97)06521-2. PMid:9201432.

Horner, H. T., Cervantes-Martinez, T., Healy, R., Reddy, M. B., Deardorff, B. L., Bailey, T. B., Al-Wahsh, I., Massey, L. K., \& Palmer, R. G. (2005). Oxalate and phytate concentrations in seeds of soybean cultivars [Glycine max (L.) Merr.]. Journal of Agricultural and Food 
Chemistry, 53(20), 7870-7877. http://dx.doi.org/10.1021/jf051193i. PMid:16190644.

Hotz, C., Loechl, C., Lubowa, A., Tumwine, J. K., Ndeezi, G., Nandutu Masawi, A., Baingana, R., Carriquiry, A., Brauw, A., Meenakshi, J. V., \& Gilligan, D. O. (2012). Introduction of $ß$-carotene-rich orange sweet potato in rural Uganda resulted in increased vitamin A intakes among children and women and improved vitamin A status among children. The Journal of Nutrition, 142(10), 1871-1880. http://dx.doi. org/10.3945/jn.111.151829. PMid:22875553.

Judprasong, K., Charoenkiatkul, S., Sungpuag, P., Vasanachitt, K., \& Nakjamanong, Y. (2006). Total and soluble oxalate contents in Thai vegetables, cereal grains and legume seeds and their changes after cooking. Journal of Food Composition and Analysis, 19(4), 340-347. http://dx.doi.org/10.1016/j.jfca.2005.04.002.

Kelsay, J. L., \& Prather, E. S. (1983). Mineral balances of human subjects consuming spinach in a low-fiber diet and in a diet containing fruits and vegetables. The American Journal of Clinical Nutrition, 38(1), 12-19. http://dx.doi.org/10.1093/ajcn/38.1.12. PMid:6305185.

Lieske, J. C., Rule, A. D., Krambeck, A. E., Williams, J. C., Bergstralh, E. J., Mehta, R. A., \& Moyer, T. P. (2014). Stone composition as a function of age and sex. Clinical Journal of the American Society of Nephrology, 9(12), 2141-2146. http://dx.doi.org/10.2215/CJN.05660614. PMid:25278549.

Messina, M. J. (1999). Legumes and soybeans: overview of their nutritional profiles and health effects. The American Journal of Clinical Nutrition, 70(3, Suppl.), 439S-450S. http://dx.doi.org/10.1093/ajcn/70.3.439s. PMid:10479216.

Nazari, S., Rameshrad, M., \& Hosseinzadeh, H. (2017). Toxicological effects of Glycyrrhiza glabra (licorice): a review. Phytotherapy Research, 31(11), 1635-1650. http://dx.doi.org/10.1002/ptr.5893. PMid:28833680.

Nguyen, H. V. H., Le, H. M., \& Savage, G. P. (2018). Effects of maturity at harvesting and primary processing of cocoa beans on oxalate contents of cocoa powder. Journal of Food Composition and Analysis, 67, 86-90. http://dx.doi.org/10.1016/j.jfca.2018.01.007.

Noonan, S. C., \& Savage, G. P. (1999). Oxalate content of foods and its effect on humans. Asia Pacific Journal of Clinical Nutrition, 8(1), 64-74. http://dx.doi.org/10.1046/j.1440-6047.1999.00038.x. PMid:24393738.

Ruan, Q. Y., Zheng, X. Q., Chen, B. L., Xiao, Y., Peng, X. X., Leung, D. W. M., \& Liu, E. E. (2013). Determination of total oxalate contents of a great variety of foods commonly available in Southern China using an oxalate oxidase prepared from wheat bran. Journal of Food Composition and Analysis, 32(1), 6-11. http://dx.doi.org/10.1016/j. jfca.2013.08.002.
Salawu, S. O., Ibukun, E. O., \& Esan, I. A. (2019). Nutraceutical values of hot water infusions of moringa leaf (Moringa oleifera) and licorice root (Glycyrrhiza glabra) and their effects on liver biomarkers in Wistar rats. Journal of Food Measurement and Characterization, 13(1), 602-613. http://dx.doi.org/10.1007/s11694-018-9973-3.

Schroder, T., Vanhanen, L., \& Savage, G. P. (2011). Oxalate content in commercially produced cocoa and dark chocolate. Journal of Food Composition and Analysis, 24(7), 916-922. http://dx.doi.org/10.1016/j. jfca.2011.03.008.

Shi, L., Arntfield, S. D., \& Nickerson, M. (2018). Changes in levels of phytic acid, lectins and oxalates during soaking and cooking of Canadian pulses. Food Research International, 107, 660-668. http:// dx.doi.org/10.1016/j.foodres.2018.02.056. PMid:29580532.

Siener, R., Bade, D. J., Hesse, A., \& Hoppe, B. (2013). Dietary hyperoxaluria is not reduced by treatment with lactic acid bacteria. Journal of Translational Medicine, 11(1), 306. http://dx.doi.org/10.1186/14795876-11-306. PMid:24330782.

Siener, R., Ebert, D., Nicolay, C., \& Hesse, A. (2003). Dietary risk factors for hyperoxaluria in calcium oxalate stone formers. Kidney International, 63(3), 1037-1043. http://dx.doi.org/10.1046/j.15231755.2003.00807.x. PMid:12631085.

Siener, R., Hönow, R., Seidler, A., Voss, S., \& Hesse, A. (2006). Oxalate contents of species of the Polygonaceae, Amaranthaceae and Chenopodiaceae families. Food Chemistry, 98(2), 220-224. http:// dx.doi.org/10.1016/j.foodchem.2005.05.059.

Siener, R., Seidler, A., Voss, S., \& Hesse, A. (2017). Oxalate content of beverages. Journal of Food Composition and Analysis, 63, 184-188. http://dx.doi.org/10.1016/j.jfca.2017.08.005.

Sönmez, Ş., Önal Darilmaz, D., \& Beyatli, Y. (2018). Determination of the relationship between oxalate degradation and exopolysaccharide production by different Lactobacillus probiotic strains. International Journal of Dairy Technology, 71(3), 741-752. http://dx.doi. org/10.1111/1471-0307.12513.

Ticinesi, A., Nouvenne, A., Chiussi, G., Castaldo, G., Guerra, A., \& Meschi, T. (2020). Calcium oxalate nephrolithiasis and gut microbiota: not just a gut-kidney axis: a nutritional perspective. Nutrients, 12(2), 548. http://dx.doi.org/10.3390/nu12020548. PMid:32093202.

Voss, S., Hesse, A., Zimmermann, D. J., Sauerbruch, T., \& von Unruh, G. E. (2006). Intestinal oxalate absorption is higher in idiopathic calcium oxalate stone formers than in healthy controls: measurements with the $\left[{ }^{13} \mathrm{C}_{2}\right]$ oxalate absorption test. The Journal of Urology, 175(5), 1711-1715. http://dx.doi.org/10.1016/S0022-5347(05)01001-3. PMid:16600737.

Yang, R., Wang, L. Q., Yuan, B. C., \& Liu, Y. (2015). The pharmacological activities of licorice. Planta Medica, 81(18), 1654-1669. http://dx.doi. org/10.1055/s-0035-1557893. PMid:26366756. 